\title{
Selection of Pityrocarpa moniliformis (Benth.) Luckow \& R. W. Jobson mother trees for seeds production
}

\author{
Francival Cardoso Felix ${ }^{1} \odot$, Josenilda Aprígio Dantas de Medeiros ${ }^{1} \odot$, Cibele dos Santos Ferrari ${ }^{1} \odot$, \\ Kyvia Pontes Teixeira das Chagas $^{1}{ }^{\circledR}$, Maria Luiza de Lima Castro ${ }^{1} \odot$, Wendy Mattos Andrade Teixeira de Souza ${ }^{1}\left({ }^{\circ}\right.$, \\ Fábio de Almeida Vieira ${ }^{1} \oplus$, Mauro Vasconcelos Pacheco ${ }^{1 *}{ }^{\circ}$ \\ 1 Universidade Federal do Rio Grande do Norte, Macaiba, RN, Brasil. E-mail: francival007@gmail.com; josi-nilda@hotmail.com; cibeferrari@hotmail.com; kyviapontes@gmail.com; \\ castro.luiza@hotmail.com; wendymattos.a@gmail.com; vieirafa@gmail.com; pachecomv@hotmail.com
}

ABSTRACT: Even though the growing demand for seeds of native forest species, for both commercial and reforestation purposes, this sector still has some challenges for the large-scale production. Harvesting of these seeds frequently takes place in natural populations, areas not registered for such use, not considering sampling criteria that guarantee their genetic conservation. Due to the economic and socio-environmental importance of Pityrocarpa moniliformis (Benth.) Luckow \& R. $W$. Jobson, a species native to the semiarid region of Brazil, this study aimed to select mother plants of $P$. moniliformis for seed production that meets the quality requirements demanded by the forest conservation and production programs. To that end, seeds from 44 trees were subjected to evaluation of physical and physiological aspects as well as of genetic diversity from mother plants and progenies by using ISSR molecular markers. There was considerable variation on the physiological quality of seeds, where $77 \%$ of $P$. moniliformis trees produced seeds with germination above $50 \%$. The progeny test showed that $64.4 \%$ of the source from total variation in the loci comes from the progenies, indicating an increased difference between generations. By considering the phytosanitary aspect, yield ( 800 seeds/individual) and seed viability (>50\%), as well as genetic diversity (Nei genetic distance $<0.78$ and progeny test), it was possible to select $27 P$. moniliformis mother plants with superior characteristics for seed production. Even though physical and physiological quality are important parameters in selecting mother plants for producing seeds intended for commercialization, the access to the genetic diversity of $P$. moniliformis assists in selecting mother plants aiming at the recovery of degraded areas, reforestation and genetic breeding. Seed-producing mother plants of $P$. moniliformis can be selected based on the genetic distance between individuals and on the physiological quality of their seeds.

Key words: dry forest; forest seeds; germination; ISSR molecular markers; physiological quality

\section{Seleção de árvores matrizes de Pityrocarpa moniliformis (Benth.) Luckow \& R.W. Jobson para produção de sementes}

RESUMO: Apesar da crescente demanda por sementes de espécies florestais nativas, tanto para fins comerciais como para reflorestamentos, o setor ainda apresenta desafios para a produção em larga escala. A coleta destas sementes frequentemente ocorre em populações naturais, em áreas não registradas para tal finalidade, sem considerar-se critérios de amostragem que garantam sua conservação genética. Devido à importância econômica e socioambiental da Pityrocarpa moniliformis (Benth.) Luckow \& R. W. Jobson, espécie nativa da região semiárida do Brasil, o objetivo deste trabalho foi selecionar matrizes de $P$. moniliformis para a produção de sementes que atendam aos requisitos de qualidade exigidos pelos programas de conservação e produção florestal. Para isso, sementes de 44 árvores foram submetidas à avaliação de aspectos físicos, fisiológicos e de

\footnotetext{
* Mauro Vasconcelos Pacheco - E-mail: pachecomv@hotmail.com (Corresponding author)

Associate Editor: Ricardo Gallo
} 
diversidade genética de matrizes e progênies com a utilização de marcadores moleculares entre sequências simples repetidas (ISSR). Observou-se considerável variação na qualidade fisiológica das sementes, onde $77 \%$ das árvores de $P$. moniliformis produziram sementes com germinação superior a $50 \%$. O teste de progênies demonstrou que $64,4 \%$ da fonte de variação total nos locos é proveniente das progênies, indicando que houve ampliação da variação entre as gerações. Considerando o aspecto fitossanitário, produtividade (800 sementes/indivíduo) e viabilidade de sementes (> 50\%), bem como a diversidade genética (distância genética de Nei < 0,78 e teste de progênies), foi possível selecionar 27 matrizes de $P$. moniliformis com características superiores para a produção de sementes. Enquanto a qualidade física e fisiológica são importantes parâmetros na seleção de matrizes para a produção de sementes destinadas à comercialização, o acesso à diversidade genética de $P$. moniliformis auxilia na seleção de matrizes visando a recuperação de áreas degradadas, o reflorestamento e o melhoramento genético. Árvores matrizes de $P$. moniliformis produtoras de sementes podem ser selecionadas com base na distância genética entre indivíduos e qualidade fisiológica de suas sementes.

Palavras-chave: florestas secas; sementes florestais; germinação; marcadores moleculares ISSR; qualidade fisiológica

\section{Introduction}

Native forest seed production in Brazil has some peculiarities when compared to the sector of the agricultural species, being substantially an activity of family and community bases (Freire et al., 2017). Simultaneously, most of the seed production areas of these species are not registered for such purpose, with the main seed sources as easily accessible trees, located in public places and within fragments with only few individuals of the same species (Freitas et al., 2015). This practice has effects that can result in seeds with low vigor and, consequently, seedlings of inferior quality. Moreover, the strategy adopted for collecting seed in these locations does not consider a minimum sampling criterion for genetic conservation (Freitas et al., 2015).

The need in formalizing the industry and the growing concern about environmental issues have led to more specific and demanding legislations, and the development of government programs prioritizing the forest restoration, thus increasing the demand for native forest seeds.

For successful environmental reforestations, seed collection requires a representative sampling of the genetic variability of one or several populations, in order to conserve the evolutionary potential of the species. Progeny and provenance tests demonstrate that the ability of a species in adapting to a new environment depends on the genetic variability between and within provenances, in addition to edaphoclimatic characteristics (Sebbenn, 2002). An inadequate sampling can restrict the genetic base of the population due to inbreeding and co-cancestry effects, and, once alleles of adaptive value are eliminated, their selfregeneration potential is reduced.

Traditionally, during the mass selection of trees to supply seed, plants are chosen phenotypically and their seeds are mixed in order to breed the next generation. However, individual selection implies in progeny testing the selected trees, where their individuality is mantained throughout the program. From the progeny tests it is possible to evaluate the genetic value of the selected mother plants, besides allowing to obtain genetic parameters, which in turn indicate the potential of this material for genetic breeding (Freitas et al., 2015).

Pityrocarpa moniliformis (Benth.) Luckow \& R. W. Jobson is a tree species part of the Fabaceae family, occurring in the semi-arid of Northeastern Brazil, a region inserted in a global biome named Seasonally Dry Tropical Forests and Woodlands (SDTFW) (Queiroz et al., 2017). This species can be used in the recovery of degraded areas as well as in the wood supplying for firewood and the production of particleboard, leaves for forage in animal feed, and flowers in beekeeping for honey production (Azerêdo et al., 2011; Nascimento et al., 2015; Jesus et al., 2015).

Due to the importance of $P$. moniliformis and the need for quality seeds aiming the expansion of the economic and ecological potentials of this species in semi-arid regions, this study aimed to select mother plants of $P$. moniliformis with superior seed production characteristics, meeting the requirements of seed genetic diversity and physical and physiological quality required by conservation and forest production programs.

\section{Materials and Methods}

\section{Tree sampling and procurement of seeds}

Sixty-nine adult individuals of $P$. moniliformis were georeferenced, all of them presenting high flower production and good phytosanitary aspect of their canopy, being part of natural populations located in the municipalities of Macaíba (42 individuals) and Mossoró (27 individuals), Rio Grande do Norte state, Brazil (Figure 1).

Among the 69 sampled trees, only 44 produced enough seeds (minimum of 800 seeds) for the proposed evaluations: 20 from the municipality of Macaíba $\left(5^{\circ} 53^{\prime} 53,06^{\prime \prime} \mathrm{S}\right.$ and $35^{\circ} 21^{\prime} 39,47^{\prime \prime}$ W, with $57 \mathrm{~m}$ of altitude) and 24 from Mossoró $\left(5^{\circ} 03^{\prime} 34,51^{\prime \prime} \mathrm{S}\right.$ and $37^{\circ} 23^{\prime} 56,92^{\prime \prime}$ W, with $81 \mathrm{~m}$ of altitude) (Figure 2). Climate, annual precipitation and mean 


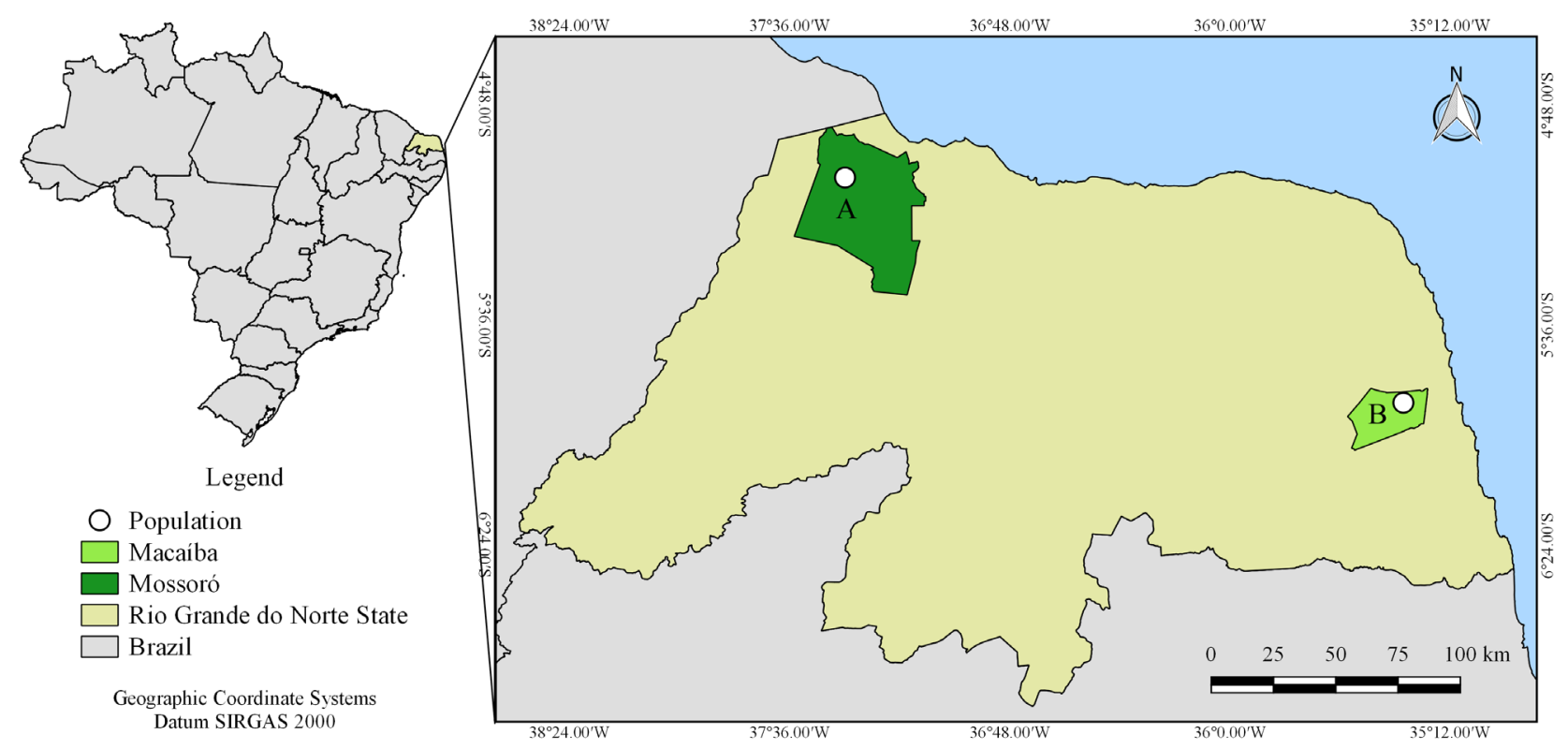

Figure 1. Location of the P. moniliformis populations in Mossoró and Macaíba, Rio Grande do Norte state, Brazil.
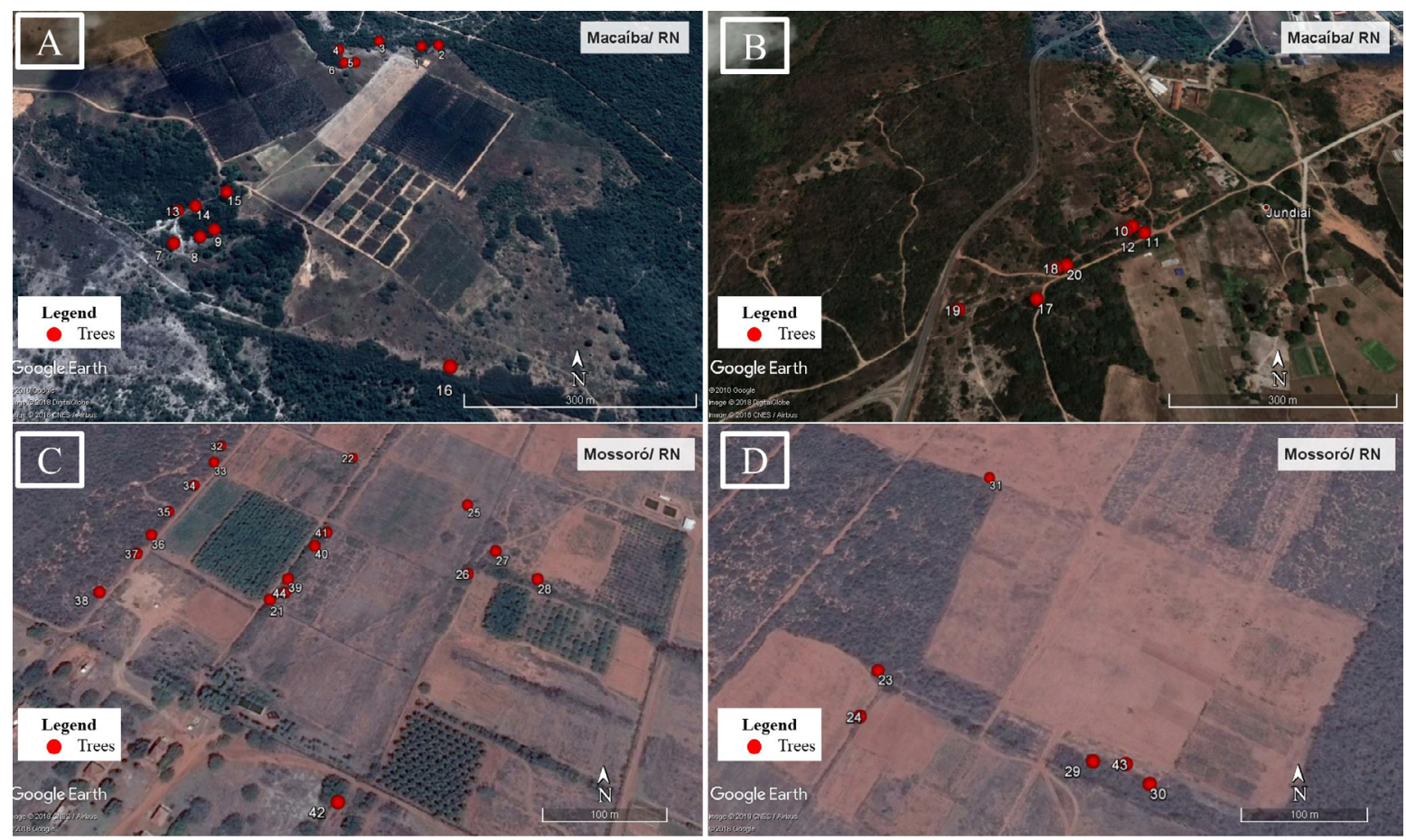

Figure 2. Location of the individuals (red dots) of P. moniliformis, 20 in Macaíba (A and B) and 24 in Mossoró (C and D), Rio Grande do Norte state, Brazil.

temperature of the municipalities of Macaíba and Mossoró are classified, respectively, as Aw and BSwh'; 1,134 and 750 $\mathrm{mm}$; and 25.8 and $28.0^{\circ} \mathrm{C}$ (Inpe, 2020).

Fruits were manually collected from the trees when they were semi-open and open, showing a brown color (5YR2/8), in the period from August to November in both 2017 and 2018. Afterwards, seed processing was carried out by manually removing the pods for physical and physiological analysis. Juvenile leaf material was also collected from the trees for DNA isolation, with the leaves transferred to tubes containing the buffer solution $2 \%$ CTAB $2 X$ detergent (cetyltrimethylammonium bromide) and stored at $-20^{\circ} \mathrm{C}$.

\section{Seed quality}

Seeds from different trees were visually separated into two portions: (1) intact seeds and (2) flat seeds or preyed by insects; these portions were then weighed on precision analytical scale $(0.001 \mathrm{~g})$, with results expressed in percentages. Physical and physiological determinations were with the portion of intact seeds.

Seed moisture was determined by oven drying at $105 \pm 3$ ${ }^{\circ} \mathrm{C}$ for $24 \mathrm{~h}$ with two replicates of $4.5 \pm 0.5 \mathrm{~g}$ of seeds for each tree, with results expressed in percentage (Brasil, 2009). Another determination was the 1000-seed weight (TSW) (Brasil, 2009) and by using it; the number of seeds per kilogram was estimated. 
Field tests of germination and seedling emergence were conducted using four replicates of 50 seeds for each tree. These seeds had their dormancy overcome by cutting off the tip of the region opposite to the hilum, followed by disinfestation in a $2.5 \%$ sodium hypochlorite solution for 5 min and later rinsing under distilled water (Brasil, 2009).

Germitest ${ }^{\oplus}$ paper towel was used for the germination test, moistened with distilled water at 2.5 times its dry weight, which were then organized in the rolls system and placed in a B.O.D. (Biochemical Oxygen Demand) germinator at a temperature of $25^{\circ} \mathrm{C}$ and photoperiod of $12 \mathrm{~h}$ (Brasil, 2013). Evaluations performed were according to the criteria established by the Brazilian rules for testing forest seed, the Instruções para Análise de Sementes de Espécies Florestais (Brasil, 2013). These evaluations were: (a) percentage of normal seedlings (seeds whose originated seedlings had root system, shoot, terminal buds and cotyledons); (b) abnormal seedlings (seeds that originated damaged, deformed or deteriorated seedlings); and (c) dead seeds 14 days after sowing; (d) germination speed index (GSI), by daily counting the number of germinated seeds after sowing in the germination test, and calculated according to the formula proposed by Maguire (1962); (e) length of normal seedlings $(\mathrm{cm})$, in which the length (tip of the main root until the apical bud) of all normal seedlings was summed, dividing the total by the number of seeds put to germinate in each replicate; (f) dry weight of normal seedlings ( $\mathrm{mg}$ ), which had their cotyledons removed and were oven dried at $65^{\circ} \mathrm{C}$ until constant weight, dividing the weight obtained at the end of drying by the number of seeds put to germinate in each replicate.

During the seedling emergence test, seeds were sown at a depth of $1.0 \mathrm{~cm}$ in a bed under full sun $(20 \mathrm{~cm}$ high $\times 1.5 \mathrm{~m}$ wide $\times 9.0 \mathrm{~m}$ long), kept moistened with daily irrigations of 5.0 L.m $\mathrm{m}^{-2}$. Then, the following was evaluated: (g) percentage of emerged seedlings 21 days after sowing; and (h) emergence speed index (ESI), with daily counting of the number of emerged seedlings and calculated according to Maguire (1962).

\section{Genetic diversity and mother plant progenies}

Leaf samples were collected from the trees that produced seeds and their progeny sampled (normal seedlings) for DNA isolation according to the protocol proposed by Doyle \& Doyle (1987). The DNA from the samples was then quantified in a spectrophotometer (Epoch ${ }^{\mathrm{TM}}$ ) and amplified in polymerase chain reaction using seven molecular markers ISSR (Inter Simple Sequence Repeats) from the University of British Columbia (UBC $827,840,844,857,859,860$ and 873). The molecular markers ISSR were selected based on Felix et al. (2020).

Amplification reactions of DNA were performed in an automated thermal cycler (BioClycle ${ }^{\mathrm{TM}}$ ) over $1 \mathrm{~h} 40 \mathrm{~min}$ (initial denaturation at $94{ }^{\circ} \mathrm{C}$ for $2 \mathrm{~min}$, followed by 37 cycles of 15 $\mathrm{s}$ at $94{ }^{\circ} \mathrm{C}$ for denaturation, $30 \mathrm{~s}$ at $47{ }^{\circ} \mathrm{C}$ for annealing ISSR primers, and $1 \mathrm{~min}$ at $72{ }^{\circ} \mathrm{C}$ for extension, with final extension at $72{ }^{\circ} \mathrm{C}$ for $7 \mathrm{~min}$ and cooling to $4{ }^{\circ} \mathrm{C}$ ). Afterwards, the PCR product was stained with bromophenol blue and GelRed ${ }^{\mathrm{TM}}$, applied in an agarose gel $\left(1.5 \mathrm{~m} . \mathrm{v}^{-1}\right)$, inserted in a horizontal electrophoresis system containing the buffer solution TAE $1 \mathrm{X}$ (Tris-acetate-EDTA), under low light, immersed and kept in an electric current of $100 \mathrm{~V}$ for $2 \mathrm{~h} 30 \mathrm{~min}$. Resulting product of electrophoresis was photographically captured under ultraviolet light in a photodocumentator (E-Box VX2).

\section{Data analysis and selection of mother plants}

For the experimental designs adopted, the entirely randomized and randomized block design were used for the germination and seedling emergence tests, respectively. Data in percentages were transformed in $\operatorname{arc} \operatorname{sen}(\operatorname{arc} \operatorname{sen}(\mathrm{V} x / 100))$ and put to Lillefors normality tests at the $5 \%$ probability level. After meeting the assumptions of normality and homogeneity, the analysis of variance was performed by using the $F$ test, with means compared by the Scott-Knott test at the $5 \%$ probability level. BioEstat ${ }^{\circ}$ (version 5.3) was the used statistical program (Ayres et al., 2007).

Allelic frequencies used for the genetic diversity evaluation were obtained in presence (1) and absence (0) of the amplified loci in each ISSR primer for the 44 individuals of $P$. moniliformis. Genetic diversity was evaluated by Nei genetic distance and Shannon index. Popgene (version 1.3) was the statistical program used (Yeh et al., 1997).

Among the seeds-producing trees with intermediate and higher physiological quality, with minimum 50\% viability, based on the abovementioned germination test, 18 individuals ( 53\%) were randomly sampled $(1,2,9,10,16,17,18,19,20$, $23,24,26,27,28,34,37,41$ and 43 ) to compose the progeny test (10 seedlings per mother plant), evaluated by the same genetic parameters as the parent trees (Nei genetic distance and Shannon index). Estimation of variance between mother plants and progenies was with molecular analysis of variance (AMOVA), having 18 mother plants and 10 individuals per mother plant, where the total genetic variance $\left(\sigma_{\mathrm{T}}{ }^{2}\right)$ corresponds to the sum of the variance between progenies $\left(\sigma_{p}{ }^{2}\right)$ and the variance between mother plants $\left(\sigma_{m}{ }^{2}\right)$, where the variance components were tested from the $\Phi_{S T}$ coefficient with 10,000 resampling, which represents the value of progenies taken at random within the mother plants in relation to those taken at random in the entire sample (Excoffier et al, 1992). Arlequin 2,000 was the program used in this case (Schneider et al., 2000).

Genetic identity dendrograms for the 44 trees and the 180 progenies were made using the UPGMA "Unweighted Pair Group Method with Arithmetic Mean" clustering method, aided by the NTSYS program (version 2.11) (Rohlf, 2000). The final selection of seed-producing mother plants was based on genetic diversity values (Nei genetic distance) within formed groups and superior performance of seed physical and physiological quality (high and medium vigor).

\section{Results and Discussion}

Among the sampled P. moniliformis individuals, 64\% produced seeds in sufficient quantity for the present study (48\% of those sampled in Macaíba and $89 \%$ in Mossoró). This 
fact is due to the large number of inflorescences and fruit abortion found in $36 \%$ of the trees, regardless of being close or not to those that produced seeds.

Seed production is influenced by biotic and abiotic factors, which can affect fruit maturation, seed formation and quantity per individual (Marcos Filho, 2016). Macaíba and Mossoró mainly show differences in temperature conditions and rainfall, which can influence fruit maturation and favor attacks on flowers, fruit, and seeds by insects and fungi.

During flowering (from December to April) (Inpe, 2020), there is more precipitation in Macaíba when compared to Mossoró, which could cause damage to inflorescences and fell them on the field, while during fruit maturation (from May to November), Mossoró has less precipitation and higher temperature, preventing an excessive relative humidity during maturation and accelerating the seed dehydration process.

In addition to that, the production differences found among individuals of native forest species are due to phenological variations and population density of reproductive individuals, associated with the reproduction systems of the species (Sousa et al., 2015). In this regard, P. moniliformis pollination is entomological and the reproductive system is allogamous, with hermaphrodite and male flowers in the same inflorescence (andromonoecious species) (Nascimento \& Dantas, 2018); in other words, in order to have efficiency in seed production, abundance of pollinating agents in the region is necessary.

P. moniliformis trees produce seeds with distinct predation levels, in which $84 \%$ of the trees produced seeds with percentage of intact seeds greater than $50 \%$, in relation to flat seeds and/or predated by insects, while $66 \%$ of the trees produced intact seeds with percentage greater than $70 \%$ (Table 1). In the present study, seed predation by Callosobruchus maculatus (Coleoptera: Bruchidae) could be observed, corroborating the study of Correia et al. (2017), in which they found high predation rates by insects when fruits are still attached to the mother plant.

Seed moisture degree of $P$. moniliformis ranged from 8.3 to $11.1 \%$ during the physiological tests of germination and vigor (Table 1). This initial evaluation is essential, and the moisture degree should be below $13 \%$ to avoid intensive deterioration processes (Guareschi et al., 2015) and enable quality comparison among lots.

$P$. moniliformis trees produce seeds with distinct densities, which is evidenced by the 1000 -seed weight (TSW), where a variation from 26.9 to $51.5 \mathrm{~g}$ of seeds was found among the trees or, namely, from 37,200 to 19,400 seeds per kilogram, respectively (Table 1). Determining the TSW and the number of seeds per kilogram are also fundamental physical analyses (Roveri Neto \& Paula, 2017). This variable, the 1000-seed weight, is used to calculate: the sowing density, an important information for planning planting or seedling production in the nursery; the number of seeds per package; and the working sample weight for purity analysis, when not specified in the Brazilian rules for seed testing, the Regras Para Análise de Sementes (Brasil, 2009).
Instructions for Forest Seed Analysis indicate that there are approximately 26,000 units per kilogram, and classify $P$. moniliformis seeds as small (TSW $<200 \mathrm{~g}$ ), with each seed lot of this species is limited to a maximum weight of 250 kg (Brasil, 2013). However, edaphoclimatic conditions and genetic diversity of non-domesticated forest species hinders an accurate standardization of the 1000-seed weight for each species, or even the range of the seed unit number that can be found per kilogram.

For all variables related to seed physiological aspects, a significant effect was observed at the $1 \%$ probability level, indicating that there are differences in the physiological performance of germination and vigor for seeds from different P. moniliformis trees (Table 2).

Among the 44 evaluated trees, 34 P. moniliformis individuals $(77 \%)$ produced seeds with germination greater than $50 \%$ (groups 3 and 4 ), while $43 \%$ (19 individuals) produced seeds with viability greater than 70\% (groups 1 and 2) (Table 2). Temperature and water availability are factors that directly affect fruit development and seed formation, as they act directly on plant metabolism (Marcos Filho, 2016). According to this author, high temperatures progressively reduce the physiological potential of legume seeds and the water deficiency impairs nutrient assimilation, thus causing reduced photosynthesis and abortion of seeds or the formation of smaller and flat seeds. More vigorous seeds were produced in the municipality of Macaíba (Table 2), whose precipitation and relative air temperature are, respectively, higher and lower when compared to the municipality of Mossoró (Inpe, 2020), which favors water upkeep in the soil, being available for the tree and preventing excessive drying of seeds during the day.

As for abnormal seedlings, their percentage was below $24 \%$, with $57 \%$ of the trees (group c) producing seeds that formed between 4 and $11 \%$ of these seedlings, having no significant difference (Table 2). During the course of the experiment, we identified polyembryony in one seed, fourteen cases of seedlings with three cotyledons, one seedling with four cotyledons, as well as one seed that had its embryonic axis on the opposite side of the micropyle.

In this study, $23 \%$ of the trees produced seeds with germination below $50 \%$ (groups 5 and 6), mainly due to the presence of dead seeds (Table 2). These seeds had traces of fungal attack, which may have caused the inoculation/death of embryos during fruit maturation, still attached to the mother plant and/or during the humidity increase in germination.

Vigor tests (GSI, length and seedling dry weight) associated with the seed germination and seedling emergence tests showed differences in physiological performance between the seeds of $P$. moniliformis trees (Table 2). Therefore, based on the physiological performance of germination and vigor of seeds from the $34 P$. moniliformis trees that had $50 \%$ viability at least, $56 \%$ of the trees produced high quality seeds $(2,8$, $9,10,11,12,14,17,18,19,20,23,24,25,27,29,32,36$ and $43)$ while $44 \%$ had intermediate quality $(1,7,13,15,16,26$, 28, 30, 31, 33, 34, 35, 37, 38 and 41) (Table 2). Differences 
Table 1. Sanitary and physical aspects of seeds from different trees of $P$. moniliformis in Macaíba and Mossoró, Rio Grande do Norte state, Brazil.

\begin{tabular}{|c|c|c|c|c|c|c|}
\hline \multirow[b]{2}{*}{ Tree } & \multirow[b]{2}{*}{ Municipality } & \multicolumn{2}{|c|}{ Seeds (\%) } & \multirow[b]{2}{*}{$\begin{array}{c}\text { Moisture } \\
\text { degree (\%) }\end{array}$} & \multirow[b]{2}{*}{$\begin{array}{l}\text { 1000-seed } \\
\text { weight (g) }\end{array}$} & \multirow{2}{*}{$\begin{array}{l}\text { Seed quantity } \\
\text { per kilogram } \\
\text { ( } x \text { thousand) }\end{array}$} \\
\hline & & Intact & $\begin{array}{l}\text { Flat or predated } \\
\text { by insects }\end{array}$ & & & \\
\hline 1 & Macaíba & 72.3 & 27.7 & 10.1 & 35.5 & 28.2 \\
\hline 2 & Macaíba & 86.7 & 13.3 & 10.5 & 41.7 & 24.0 \\
\hline 3 & Macaíba & 33.8 & 66.2 & 10.9 & 33.8 & 29.5 \\
\hline 4 & Macaíba & 81.0 & 19.0 & 10.2 & 47.2 & 21.2 \\
\hline 5 & Macaíba & 71.8 & 28.2 & 9.5 & 26.9 & 37.2 \\
\hline 6 & Macaíba & 88.7 & 11.3 & 9.0 & 49.8 & 20.1 \\
\hline 7 & Macaíba & 33.7 & 66.3 & 9.3 & 34.5 & 29.0 \\
\hline 8 & Macaíba & 76.2 & 23.8 & 10.5 & 40.9 & 24.4 \\
\hline 9 & Macaíba & 63.2 & 36.8 & 8.4 & 38.6 & 25.9 \\
\hline 10 & Macaíba & 82.7 & 17.3 & 10.9 & 32.8 & 30.5 \\
\hline 11 & Macaíba & 95.2 & 4.8 & 8.7 & 36.1 & 27.7 \\
\hline 12 & Macaíba & 64.1 & 35.9 & 9.4 & 34.2 & 29.2 \\
\hline 13 & Macaíba & 78.1 & 21.9 & 9.2 & 51.5 & 19.4 \\
\hline 14 & Macaíba & 78.9 & 21.1 & 8.6 & 40.5 & 24.7 \\
\hline 15 & Macaíba & 75.4 & 24.6 & 8.6 & 36.3 & 27.5 \\
\hline 16 & Macaíba & 87.4 & 12.6 & 9.5 & 35.3 & 28.3 \\
\hline 17 & Macaíba & 93.9 & 6.1 & 10.8 & 33.9 & 29.5 \\
\hline 18 & Macaíba & 55.2 & 44.8 & 9.2 & 32.4 & 30.8 \\
\hline 19 & Macaíba & 80.6 & 19.4 & 9.4 & 34.7 & 28.8 \\
\hline 20 & Macaíba & 76.9 & 23.1 & 8.3 & 30.1 & 33.3 \\
\hline 21 & Mossoró & 74.8 & 25.2 & 10.3 & 34.4 & 29.0 \\
\hline 22 & Mossoró & 42.6 & 57.4 & 9.2 & 31.6 & 31.6 \\
\hline 23 & Mossoró & 82.9 & 17.1 & 9.7 & 36.1 & 27.7 \\
\hline 24 & Mossoró & 85.7 & 14.3 & 11.1 & 38.0 & 26.3 \\
\hline 25 & Mossoró & 69.6 & 30.4 & 11.0 & 42.8 & 23.4 \\
\hline 26 & Mossoró & 77.1 & 22.9 & 9.3 & 44.4 & 22.5 \\
\hline 27 & Mossoró & 77.1 & 22.9 & 8.7 & 41.3 & 24.2 \\
\hline 28 & Mossoró & 66.8 & 33.2 & 8.7 & 41.8 & 23.9 \\
\hline 29 & Mossoró & 83.5 & 16.5 & 10.3 & 37.1 & 27.0 \\
\hline 30 & Mossoró & 78.6 & 21.4 & 8.5 & 43.0 & 23.2 \\
\hline 31 & Mossoró & 66.4 & 33.6 & 9.6 & 35.4 & 28.3 \\
\hline 32 & Mossoró & 78.3 & 21.7 & 9.8 & 31.8 & 31.5 \\
\hline 33 & Mossoró & 90.0 & 10.0 & 9.2 & 36.0 & 27.8 \\
\hline 34 & Mossoró & 67.1 & 32.9 & 8.4 & 32.9 & 30.4 \\
\hline 35 & Mossoró & 7.1 & 92.9 & 8.4 & 35.6 & 28.1 \\
\hline 36 & Mossoró & 91.1 & 8.9 & 10.2 & 50.9 & 19.6 \\
\hline 37 & Mossoró & 37.2 & 62.8 & 10.0 & 42.4 & 23.6 \\
\hline 38 & Mossoró & 77.4 & 22.6 & 9.8 & 40.9 & 24.4 \\
\hline 39 & Mossoró & 81.5 & 18.5 & 8.3 & 37.2 & 26.9 \\
\hline 40 & Mossoró & 53.2 & 46.8 & 9.5 & 27.0 & 37.1 \\
\hline 41 & Mossoró & 49.7 & 50.3 & 9.8 & 37.7 & 26.5 \\
\hline 42 & Mossoró & 92.6 & 7.4 & 8.8 & 35.6 & 28.1 \\
\hline 43 & Mossoró & 69.9 & 30.1 & 9.1 & 41.2 & 24.3 \\
\hline 44 & Mossoró & 49.0 & 51.0 & 10.5 & 29.4 & 34.0 \\
\hline \multicolumn{2}{|c|}{ Mean Macaíba } & 73.8 & 26.2 & 9.6 & 37.3 & 27.5 \\
\hline \multicolumn{2}{|c|}{ Mean Mossoró } & 68.7 & 31.3 & 9.5 & 37.7 & 27.1 \\
\hline
\end{tabular}

in seed physiological quality from trees of the same region or between different areas were also observed for Ceiba speciosa St. Hil (Roveri Neto \& Paula, 2017) and Aspidosperma pyrifolium Mart. (Correia et al., 2019).

For the efficient production of $P$. moniliformis seeds, besides the physical and physiological aspects of the seeds, the genetic attributes of the individuals have to be considered in order to ensure that the genetic diversity of the species is kept in seeds. To that end, the trees showed diversity indices of Nei and Shannon, respectively, $h_{e}=0.292 \pm 0.023$ and $I=$ $0.449 \pm 0.029$ (mean \pm standard error), with occurrence of 70 polymorphic loci, or $95 \%$ of the total loci.

Thereby, based on the genetic diversity of the 44 trees (Figure 3 ), eight groups were observed (Groups: 9-10-19; 6-7-8; 2-4; 1718-20; 22-23-24; 27-28-29-30-31-36-39-40-41-43; 21-25-26-3233-34-35-37-38-42-44; and 1-11-12-13-14-15) formed at the level of 0.78 in the similarity dendrogram, in addition to three more divergent isolated individuals ( 3,5 and 16$)$. 
Table 2. Physiological aspects [Germination, abnormal seedlings, dead seeds, germination speed index, length and seedling dry weight, emergence and emergence speed index], of seeds from different tree groups of $P$. moniliformis in Macaíba and Mossoró, Rio Grande do Norte state, Brazil.

\begin{tabular}{|c|c|}
\hline Groups* & Trees** \\
\hline \multicolumn{2}{|l|}{ Germination } \\
\hline Group 1 (a) & $2,8,9,10,12,14,17,18,19,32$ and 43 \\
\hline Group 2 (b) & $11,20,23,24,25,27,29$ and 36 \\
\hline Group 3 (c) & $7,13,15,26,28,30,31,33,37,38$ and 41 \\
\hline Group 4 (d) & $1,16,34$ and 35 \\
\hline Group 5 (e) & $3,5,6$ and 21 \\
\hline Group 6 (f) & 42 \\
\hline Group 7 (g) & $4,22,39,40$ and 44 \\
\hline \multicolumn{2}{|c|}{ Abnormal seedlings } \\
\hline Group 1 (a) & $15,26,30,31,38$ and 42 \\
\hline Group 2 (b) & $1,4,5,16,21,23,24,25,27,29,33$ and 39 \\
\hline Group 3 (c) & $2,3,6,7,8,9,10,11,12,13,14,17,18,19,20,22,28,32,34,35,36,37,40,41,43$ and 44 \\
\hline \multicolumn{2}{|r|}{ 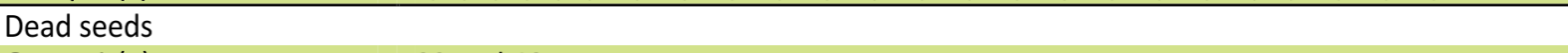 } \\
\hline Group 1 (a) & 22 and 40 \\
\hline Group 2 (b) & 4, 39 and 44 \\
\hline Group 3 (c) & $3,6,21$ and 42 \\
\hline Group 4 (d) & $5,7,16,34,35$ and 41 \\
\hline Group 5 (e) & $1,13,26,28,30,31,33$ and 37 \\
\hline Group 6 (f) & $11,12,15,18,19,20,25,27,29,36$ and 38 \\
\hline Group 7 (g) & $2,8,9,10,14,17,23,24,32$ and 43 \\
\hline \multicolumn{2}{|r|}{ ( } \\
\hline Group 1 (a) & $2,8,9,10,14,17,18,19,23,24$ and 27 \\
\hline Group 2 (b) & $11,12,20,25,36$ and 43 \\
\hline Group 3 (c) & $13,29,30,31,32,33$ and 38 \\
\hline Group 4 (d) & $7,26,34$ and 41 \\
\hline Group 5 (e) & $1,16,28,35$ and 37 \\
\hline Group 6 (f) & 3,5 and 6 \\
\hline Group 7 (g) & 15 and 21 \\
\hline Group 8 (h) & 4 and 42 \\
\hline Group 9 (i) & 22 and 44 \\
\hline Group $10(\mathrm{j})$ & 39 and 40 \\
\hline \multicolumn{2}{|l|}{ Seedlings length } \\
\hline Group 1 (a) & 43 \\
\hline Group 2 (b) & $8,9,14,17$ and 18 \\
\hline Group 3 (c) & $2,10,11,12,13,19,20,24,25,32,36$ and 37 \\
\hline Group 4 (d) & $23,26,27,28,29,31,33,34,35,38$ and 41 \\
\hline Group 5 (e) & $1,3,5,6,7,16,21$ and 30 \\
\hline Group 6 (f) & $4,15,22,39,40,42$ and 44 \\
\hline \multicolumn{2}{|c|}{ Seedlings dry weight } \\
\hline Group 1 (a) & $2,9,14,36$ and 43 \\
\hline Group 2 (b) & 8,17 and 25 \\
\hline Group 3 (c) & $10,13,18,23,24,26,27,37$ and 38 \\
\hline Group 4 (d) & $11,12,19,20,28,29,31,32,33,34$ and 41 \\
\hline Group 5 (e) & $1,3,5,6,7,16,21,30$ and 35 \\
\hline Group 6 (f) & $4,15,22,39,40,42$ and 44 \\
\hline \multicolumn{2}{|c|}{ Seedlings emergence } \\
\hline Group 1 (a) & $8,10,14,17,18,23,24,25,27,29,36$ and 43 \\
\hline Group 2 (b) & $2,9,11,12,13,15,19,20,26,30,32,33,37,38$ and 41 \\
\hline Group 3 (c) & $1,7,16,31$ and 35 \\
\hline Group 4 (d) & $3,5,6,21,28$ and 34 \\
\hline Group 5 (e) & $4,22,39,40,42$ and 44 \\
\hline \multicolumn{2}{|l|}{ ESI } \\
\hline Group 1 (a) & 24,25 and 43 \\
\hline Group 2 (b) & $8,14,18,23$ and 38 \\
\hline Group 3 (c) & $9,11,12,13,17,19,20,26,27,29,30,32,33,35,36,37$ and 41 \\
\hline Group 4 (d) & $1,2,6,7,10,15,16,21,28,31,34$ and 42 \\
\hline Group 5 (e) & $3,4,5,22,39,40$ and 44 \\
\hline
\end{tabular}

*Groups of each variable were classified according to the Scott-Knott test at $5 \%$ probability, in which greater values were found in groups closer to those of the "a" letter.

**Trees of P. moniliformis from Macaíba (1-20) and Mossoró (21-44), Rio Grande do Norte state, Brazil. 


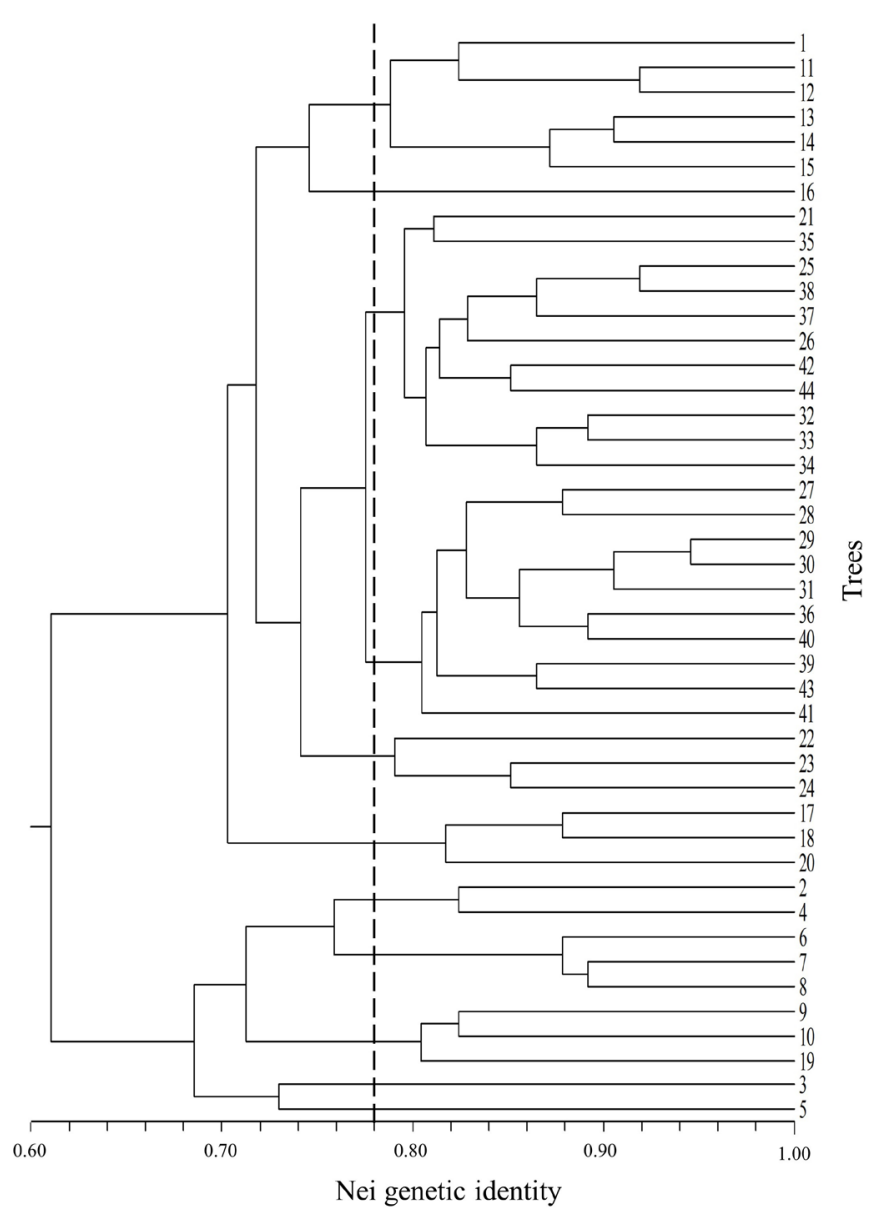

Figure 3. Dendrogram based on Nei genetic distance for $P$. moniliformis trees with cut level of 0.78 .

Among the 34 trees that produced seeds with viability above 50\% (Table 2 ), 18 ( 53\%) were randomly sampled (1, $2,9,10,16,17,18,19,20,23,24,26,27,28,34,37,41$ and 43 ) to compose the progeny test (Figure 4). Progenies of the respective mother plants of $P$. moniliformis formed two distinct groups at the level of 0.88 (Figure 4), with the mother plants of Macaíba and Mossoró composing, respectively, the first $(1,2,9,10,16,17,18,19$ and 20$)$ and second $(23,24,26$, $27,28,34,37$ and 41 ) groups; and a more divergent tree that did not form any group (43).

180 progenies from 18 P. moniliformis individuals presented $64.4 \%$ of the total variation source of the loci, and that only $35.6 \%$ are due to variation between mother plants (Table $3)$, thus demonstrating there is an amplification of variation between generations. Greater genetic diversity observed in the progenies is because the mother plants are located in open environments, which are receptive to pollen from the other trees in the population. Nei and Shannon diversity indexes among

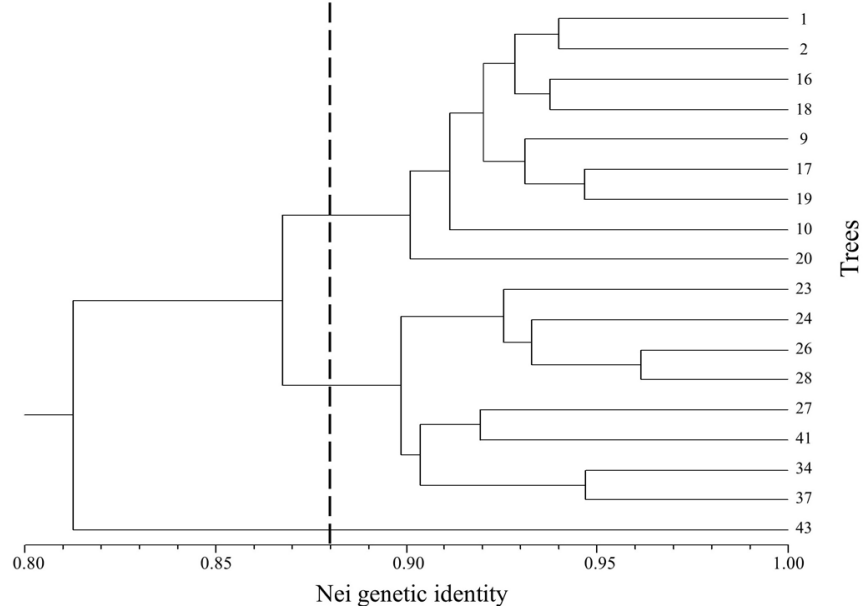

Figure 4. Dendrogram based on Nei genetic distance for the progenies from $P$. moniliformis trees with cut level of 0.88 .

the progenies were $h_{e}=0.239 \pm 0.014$ and $I=0.369 \pm 0.018$ (mean \pm standard error), respectively, with the occurrence of 63 polymorphic loci, or $85 \%$ of the total loci. These indexes are close to the standard error found with the evaluation of 44 trees, that is, the progenies of $P$. moniliformis trees keep their genetic diversity even with a reduction in the number of individuals.

Given the foregoing, progenies of these mother plants maintain the segregated genes of their populations of origin and the suggestion is to obtain seeds from several mother plants from the same region and between different regions in order to increase the seed production genetic diversity. Studies with progenies, which will form new populations, contribute in verifying the maintenance of genetic diversity of the source populations, especially when dealing with reduced populations and in anthropized areas.

However, among the 44 evaluated trees in this study, 27 P. moniliformis individuals $(2,8,9,10,11,12,13,14,15,16$, $17,18,19,20,23,24,25,26,27,29,30,32,33,36,38,41$ and 43) listed as seed-producing mother plants. When in the same group, determined by Nei distance at the 0.78 level (Figure 4), at least one individual was selected from each of the formed groups, considering viability (greater than 50\%) and greater vigor (Table 2). Thereby, these selected mother plants, besides meeting the criteria of seed phytosanitary and yield, showed the highest indexes of genetic diversity and produced seeds of high and medium physiological quality (viability and vigor).

Selecting mother plants of $P$. moniliformis is considered an important step in seed production because it increases the final quality of the seed lot for sowing, marketing or storage, as illustrated in Table 4. Composition of the seed lot by selected mother plants of $P$. moniliformis is higher than when compared to the composition with seed lots from all trees, regardless if

Table 3. Molecular analysis of variance (AMOVA) for the 18 trees and 180 progenies of $P$. moniliformis based on the ISSR markers.

\begin{tabular}{ccccc}
\hline Variation source & Degrees of freedom & Sum of squares & Variance components & Total variation ${ }^{*}$ \\
\hline Mother plants & 17 & 202.53 & 1.009 & 35.6 \\
Progenies & 162 & 295.80 & 1.826 & 64.4 \\
\hline Total & 179 & 498.33 & 2.835 & \\
\hline
\end{tabular}

"Significant at the $5 \%$ level of probability 
Table 4. Physiological aspects [Germination (G), abnormal seedlings (AS), dead seeds (DS), germination speed index (GSI), length (SL) and seedling dry weight (SDW), emergence (E) and emergence speed index (ESI)] for composing the batch of seeds from selected mother plants of $P$. moniliformis.

\begin{tabular}{|c|c|c|c|c|c|c|c|c|}
\hline Seed batch & $\mathbf{G}$ & $\begin{array}{l}\text { AS } \\
\text { (\%) }\end{array}$ & DS & GSI & $\begin{array}{c}\text { SL } \\
\text { (cm) }\end{array}$ & $\begin{array}{l}\text { SDW } \\
\text { (mg) }\end{array}$ & $\begin{array}{c}E \\
(\%)\end{array}$ & ESI \\
\hline Selected trees & $77 a$ & $10 \mathrm{a}$ & $14 \mathrm{~b}$ & $12.7 \mathrm{a}$ & $7.1 \mathrm{a}$ & $5.8 \mathrm{a}$ & $62 a$ & $2.8 \mathrm{a}$ \\
\hline All trees & $62 \mathrm{~b}$ & $10 \mathrm{a}$ & 29 a & $10.0 \mathrm{~b}$ & $5.4 \mathrm{~b}$ & $4.5 \mathrm{~b}$ & $46 \mathrm{~b}$ & $2.1 \mathrm{~b}$ \\
\hline$F$ value & $37.37^{* *}$ & $0.01^{\text {ns }}$ & $36.93^{* *}$ & $35.60^{* *}$ & $26.23^{* *}$ & $23.95^{* *}$ & $38.79^{* *}$ & $21.90^{*}$ \\
\hline
\end{tabular}

${ }^{\mathrm{ns}}$ non-significant and ${ }^{* *}$ significant at $1 \%$ level of probability by the $\mathrm{F}$ test.

they are selected or not (sampling). Furthermore, the genetic diversity represented by these mother plants contributes to forming new forest stands for the recovery of degraded areas, reforestation, commercial planting and genetic breeding.

\section{Conclusions}

P. moniliformis trees produce seeds different in physical and physiological quality, thus becoming important parameters in the individual selection of mother plants for the production of seeds that meet the commercialization requirements.

Accessing the genetic diversity of $P$. moniliformis helps in selecting mother plants for seed production aiming at the recovery of degraded areas, reforestation and commercial planting, besides providing subsidies for the genetic improvement of the species.

Seed-producing mother plants of $P$. moniliformis can be selected based on the genetic distance between individuals and on the physiological quality of their seeds.

\section{Acknowledgements}

This study was conducted with support from the "National Council for Scientific and Technological Development (CNPq)" and "Coordination for the Improvement of Higher Education Personnel - Brazil (CAPES) - Finance Code 001". To Laboratory of Genetic and Forest Improvement (LabGen) of Federal University of Rio Grande do Norte (UFRN), for provide structure for the development of the study. Access to the genetic heritage of this research is registered under the National System for the Management of Genetic Heritage and Associated Traditional Knowledge (SisGen) and identified by the codes A0C8FD7 and A5DB85E.

\section{Compliance with Ethical Standards}

Author contributions: Conceptualization: MVP; Data curation: MLLC, WMATS; Investigation: FCF; Methodology: CSF, FAV; Project administration: MVP; Writing - original draft: FCF, JADM, KPTC; Writing - review \& editing: FCF, JADM, KPTC.

Conflict of Interest: There is no conflict of interest.

Funding: National Council for Scientific and Technological Development (CNPq) - Process 437955/2018-4 and Coordination for the Improvement of Higher Education Personnel - Brazil (CAPES) - Finance Code 001.

\section{Literature Cited}

Ayres, M.; Ayres Júnior, M.; Ayres, D.L.; Santos, A.D. BioEstat 5.0: aplicações estatísticas na área das ciências biológicas e biomédicas. 5.ed. Tefé: Instituto de Desenvolvimento Sustentável Mamirauá, 2007. 364p.

Azerêdo, G.A.; Paula, R.C.; Valeri, S.V. Determining the viability of Piptadenia moniliformis Benth. seeds with the tetrazolium test. Journal of Seed Science, v.33, n.1, p.61-68, 2011. https://doi.org/10.1590/S010131222011000100007.

Brasil. Ministério da Agricultura, Pecuária e Abastecimento. Instruções para a análise de sementes de espécies florestais. Brasília: MAPA; ACS, 2013. 98p.

Brasil. Ministério da Agricultura, Pecuária e Abastecimento. Regras para análise de sementes. Brasília: MAPA; ACS, 2009. 399p.

Correia, L.A.S.; Felix, F.C.; Araújo, F.S.; Ferrari, C.S.; Pacheco, M.V. Morphometric descriptors and physiological seed quality for selecting Aspidosperma pyrifolium Mart. matrix trees. Revista Caatinga, v.32, n.3, p.751-759, 2019. https://doi.org/10.1590/198321252019v32n319rc.

Correia, L.A.S.; Medeiros, J.A.D.; Silva, A.B.; Ferrari, C.S.; Pacheco, M.V. Physiological quality of catanduva seeds under Callosobruchus maculatus (Coleoptera: Bruchidae) infestation. Revista Agropecuária Técnica, v.38, n.2, p.65-70, 2017. http://www.periodicos.ufpb.br/ojs/ index.php/at/article/view/29838. 29 Mar. 2020.

Doyle, J.J.; Doyle, J.L. Isolation of plant DNA from fresh tissue. Focus, v.12, n.1, p.13-15, 1987.

Excoffier, L.; Smouse, P.; Quattro, J. Analysis of molecular variance inferred from metric distances among DNA haplotypes: application to human mitochondrial DNA restriction data. Genetics, v.131, n.2, p.479-491, 1992. https://www.ncbi.nlm.nih.gov/pubmed/1644282. 19 Mar. 2020.

Felix, F.C.; Chagas, K.P.T.; Ferrari, C.S.; Vieira, F.A.; Pacheco, M.V. Applications of ISSR markers in studies of genetic diversity of Pityrocarpa moniliformis. Revista Caatinga, v.33, n.4, p.1017-1024, 2020. https:// doi.org/10.1590/1983-21252020v33n417rc

Freire, J. M.; Urzedo, D. I.; Pina-Rodrigues, F. C. M. A realidade das sementes nativas no Brasil: Desafios e oportunidades para a produção em larga escala. Seed News, v.25, n.1, p. 24-28, 2017.

Freitas, M. L. M.; Aguiar, A. V.; Spoladore, J., Sousa, V. A.; Sebbenn, A. M. Produção de sementes de espécies florestais nativas: estratégias de melhoramento In: Pinã-Rodrigues, F.C.M.; Figliolia, M.B.; Da Silva, A. (Orgs.) Sementes Florestais Tropicais: da ecologia à produção. Londrina: Abrates, p.285-307. 2015.

Guareschi, D.G.; Lanzarini, A.C.; Lazarotto, M.; Gonzatto, C.; Barbieri, G. Accelerate aging and seedling quality of Bauhinia forficata Link on different substrates and containers size. Revista Agro@ mbiente On Line, v.9, n.1, p.65-71, 2015. https://doi.org/10.5327/ Z1982-8470201500012175. 
Instituto Nacional de Pesquisas Espaciais - Inpe. Centro de Previsão de Tempo e Estudos Climáticos. Monitoramento Brasil. http:// clima1.cptec.inpe.br/monitoramentobrasil/pt. 01 Apr. 2020.

Jesus, M.C.; Borges, R.L.B.; Souza, B.A.; Brandão, H.N.; Santos, F.A.R. A study of pollen from light honeys produced in Piauí State, Brazil. Palynology, v.39, n.1, p.110-124, 2015. https://doi.org/10. 1080/01916122.2014.942440.

Maguire, J.D. Speed of germination-aid seedling emergence and vigor. Crop Science, v.2, n.2, p.176-177, 1962. https://doi.org/10.2135/ cropsci1962.0011183X000200020033x.

Marcos Filho, J. Seed physiology of cultivated plants. 2.ed. Piracicaba: FEALQ, 2016. 660p.

Nascimento, J.P.B.; Dantas, B.F. Pityrocarpa moniliformis (Benth.) Luckow \& R.W. Jobson Angico-de-bezerro. Nota Técnica ABRATES, n.8, p.1-4, 2018. https://www.abrates.org.br/img/ technical_notes/1a709793-8be7-49f8-9584-aa867c1e1d34_ Nota_T\%C3\%A9cnica_08.pdf. 03 Apr. 2020.

Nascimento, M.F.; Bertolini, M.S.; Panzera, T.H.; Christoforo, A.L.; Lahr, F.A.R. OSB panels made with wood species from the Brazilian Northeast's Caatinga. Ambiente Construído, v.15, n.1, p.41-48, 2015. https://doi.org/10.1590/S1678-86212015000100005.

Queiroz, L.P.; Cardoso, D.; Fernandes, M.; Moro, M. "Diversity and evolution of flowering plants of the Caatinga domain". In: da Silva, J. C.; Leal, I.; Tabarelli, M, (Eds.), Caatinga: the largest tropical dry forest region in South America. Cham: Springer, 2017, p. 23-63. https://doi.org/10.1007/978-3-319-68339-3_2.
Rohlf, F.J. Numerical taxonomy and multivariate analysis system version 2.1. User Guide. New York: Applied Biostatistic, 2000. $142 p$.

Roveri Neto, A.; Paula, R.C. Variability among mother trees of Ceiba speciosa St. Hil for characteristics of the fruits and seeds. Revista Ciência Agronômica, v.48, n.2, p.318-327, 2017. https://doi. org/10.5935/1806-6690.20170037.

Schneider, S.; Roessli, D.; Excoffier, L. Arlequin: a software for population genetics data analysis, version 2.000. Geneva: University of Geneva, Genetics and Biometry Laboratory, 2000. $111 p$.

Sebbenn, A.M. Número de árvores matrizes e conceitos genéticos na coleta de sementes para reflorestamentos com espécies nativas. Revista do Instituto Florestal, v.14, n.2, p.115-132, 2002. https:// smastr16.blob.core.windows.net/iflorestal/ifref/RIF14-2/RIF142_115-132.pdf. 29 Mar. 2020.

Sousa, V.A; Aguiar, A.V.; Moura, N.F.; Moraes, M.A.; Moraes, M.L.T.; Sebbenn, A.M. Fluxo gênico e estrutura genética espacial intrapopulacional e suas implicações para a coleta de sementes de espécies arbóreas tropicais. In: Piña-Rodrigues, F.C.M.; Figliolia, M.B.; Silva, A. (Orgs.). Sementes florestais tropicais: da ecologia à produção. Londrina: Abrates, 2015. p.46-82.

Yeh, F.C.; Yang, R.C.; Boyle, T.B.J.; Ye, Z.H.; Mao, J.X. Pop-gene, the user-friendly shareware for population genetic analysis molecular biology and biotechnology center. Edmonton: Molecular Biology and Biotechnology Center; University of Alberta, 1997. 